\title{
浮選槽底の攪抖に関する研究*
}

一一副旸根によるもの一

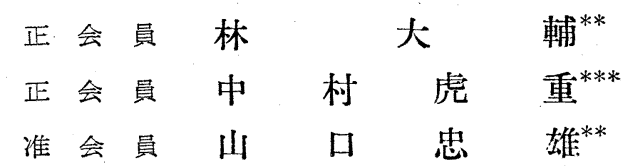

\section{Studies on Agitation at the Bottom of Flotator}

\section{Daisuke HAYSHI, Torashige NAKAMURA and Tadao YAMAGUCHI}

It is known that the function of auxiliary blades attaching to the impeller of Fahrenwald flotator is consisted in preventing settling of ore particles by applying agitation to the bottom of cell as subsidiary action assisting the main blade, while both the types of fluidization of ore particles by auxiliary blades and the relationship of the main blade with auxiliary blades have not been made distinct.

From the point of view above, the authors inspected the flow patterns at the bottom of cell employing the apparatus composed of an agitator of batch-system and a model impeller. The results obtained are as follows :-

1) The critical agitating speed at which the ore particles are fluidized is to be varied in response to the difference of geometrical condition in the relation between the cell and the impeller.

2) The critical setting-depth of impeller where the minimum critical speed is available under the same condition, is to be obtainable.

3) By lowering the critical depth with dish-like bottom to that of impeller installed and by applying bottom-agitation effectively with the main blade, the essential agitation is made possible by the minimum power.

\section{1. 緒} 言

Fahrenwald 型浮選機インペラについている副羽根 の機能は, 主羽根を補助して槽底の蚫汼を強め鉣粒の沈 降を防止するにあるが，その鉣粒の流動に及ぼす影響や 主羽根作用との相関などについては明らかにされていな W。

このような見地から，小型の回分式㩭找装置を用い， 近似一次元的な手法を主用して, 副羽根と槽に関する幾 何学的条件と鉣粒の流動限界速度との関係を解明し, 主 羽根を加えた場合との比較を併せて探求した。

\section{2. 装置と方法}

摫汼槽内に去ける固形粒子の流動, 浮遊の度合を定量 する方法 ${ }^{1223)}$ の中で, 永田法3) は著者達の使用する形状

* 昭和 33 年 10 月 11 日受理 昭和 33 年度本会秋季大会比て発表

** 鹿児島大学工学部教授 *** 鹿児島大学教育学部

a) 交献 3$), H p \geqq 0.2 D$ 飞ついて円筒槽沉櫂型インペラを使つて測定 しているが，この結果から $H p<0.2 D$ 以下の場合の推察は困難で ある上，槽底面の周壁部と中心部江静止粒子のなくなつた䐆間の軸 回転数（流限界速速度 $s n_{e}$ と $e n_{e}$ ) を判定することは, ばらつき が起しく不確実である。
のイソペラの場合に応用すると, 低インペラ設置高度 で, その流動限界速度a)の判定に困難があるが, その限 界量判定の基準を多少変更すれば十分に利用され, 簡便 であるので，実験方法の多くをこれに做うこととした。

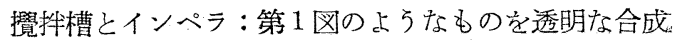

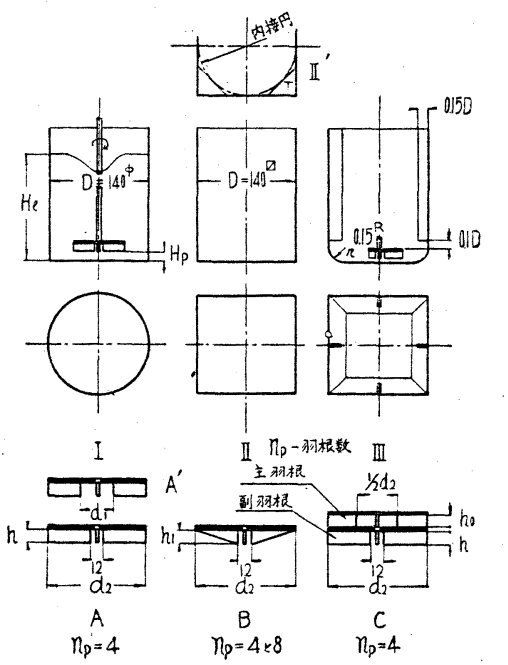

第 1 図

実験に使用し た槽とインペ ラ 
樹脂板で作成し， II と IIIの僬槽を主用に，比較として I の円筒槽をあて,インペラ A， A'，Bを副羽根単独の 機能調查用, Cを主羽根を加兄た場合の模型として利用 した。

鉣粒：球形に近い標準ガラス粉末の各粒度のものを試 用したが，微細なものほど流動限界速度の判定も困難で あり, 槽内の流相も識別しにくいので, 第 1 表の粒度組

\section{第 1 表}

\begin{tabular}{c|c}
\hline mesh & $\%$ \\
\hline+48 & \multicolumn{1}{|c}{0} \\
+60 & 10.24 \\
+65 & 49.21 \\
+80 & 28.30 \\
+100 & 4.85 \\
-100 & 7.39 \\
\hline
\end{tabular}

成のものを専用し，液の深さ $H_{l}$ $=D$ とし, これに液量の $2.5 \%$ 容 積にあたるガラス粉末を投入して 筧拌した。

粒子流動限界速度：槽底を鏡に 照して粒子の流動状態を観察し，

周壁部と中心部について, それぞれの粒子流動限界速度 $s n_{e_{2}}$ と $e_{e_{2}}$ を求めて比較の対象とした。この值のとり 方は永田法 (脚註) と原則的には同様であるが，それぞ れの部分に静止粒子がなくなつた時の值 $\left(s n_{c_{1}} \text { と }{ }_{e} n_{c_{1}}\right)^{\mathrm{b})}$ は判定が困難であるので，さらに回転数を増し最後の粒 子も相当活発に流動を始めたと確実に認められる時の回 転数を採用したので， $s n_{e_{2}}>{ }_{s} n_{c_{1}} ;{ }_{c} n_{c_{2}}>{ }_{e} n_{c_{1}}$ となる。 この限界值測定の具体的な要領を，第 2 図の角槽底の 粒子流相図について説明すると次の通りである。

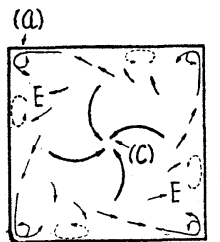

(1) $H_{p}=0.05 D$

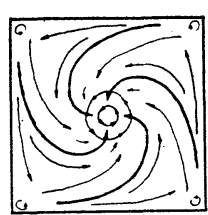

() $H p=0.4 D$

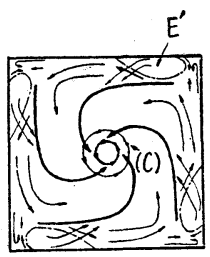

(i) $H p=0.5 D$
第 2 図 槽底のフローパターン, $\mathrm{A}$ 型 $d_{2}=0.5 D$, $h=0.05 D, 300 \mathrm{rpm}$, 角槽 II（扁平底）

周壁部一一 $H_{p}$ の低い場合は(イ)四のよ 5 亿, 回転数 の増加につれ周壁内接円内の粒子がまず流動浮遊し，以 後漸次隅の部分に区び, 最後に(a) 領域が残るので, こ の領域の粒子を対象として ${ }_{s} n_{c 2}$ をとる。 $H_{p}$ の高い場合 は(八)図つ $E^{\prime}$ が全体に先立つて透明となるが，この領 域何据せず，上と同様汇する。

中心部——この部分については円筒槽の場合と同様と して, $H_{p}$ の高低をとわず，（c）領域を対象としここに 生ずる透明化した小円内の残留粒子てついて $\mathrm{e} n_{e_{2} 2}$ をと る。

なおこのょうにして測定した限界速度值も同一 $H_{p}$

b) 交献 3)では $s n c$ と $c n e$ とされている。

c) 本報で $n_{c}$ として $s n_{c}$ と $\boldsymbol{c}_{\boldsymbol{1}}$ を别しない場合は，一般に流動限 界速度とい5意味を表わした場合と， $s n_{c}$ と $c n_{c}$ を比較して高い 方の值だけを採用したことを意味する場合とがあるが，後者では例 示の図中に $\mathrm{c} n e$ に属するすのを点線で現わしているので区別でき ๖。
についてな相当のばらつきがあり， $H_{p}$ を異にした場 合についても粒子活動のし方相違があるので, 最善の ものではない。したがつて粒子がさらに完全に浮遊化し てインペラの下部が活とんど透明化し、た時を選び，この 一定透明度 ${ }^{2)}$ を基準にした，上り高回転の $n_{e_{3}}$ を限界值 として比較する方が， $s n_{c}$ と $n_{c}$ の区別も必要とせず， 測值も容易である。この方法で $n_{c_{3}}$ を一通り測定したが 高回転のためインペラ中に空気を巻込むことが多く，一 部に応用できただけであつた。

第 3 図は槽 I とよる $H_{p}$ と $n_{e_{1}} n_{c_{2}}, n_{e_{3}}{ }^{\mathrm{c}}$ との関係の 例示である。

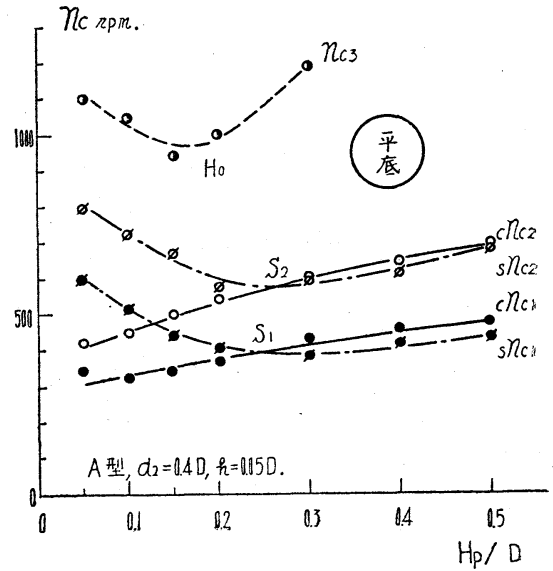

(ㅁ)

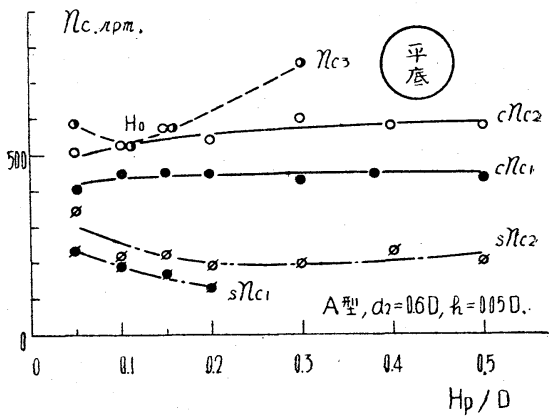

第 3 図 測定基準の相違と粒子の流動限界速度 $n_{c}$

補助測定：本実験では既存の 報告334) 飞詳細でない低 $H_{p}$ の範囲を重視して扱い，その結果る新しいものがあ るので,測定值の確害性の裏うけを兼ねて，槽底部ととの 関連部分の水の流相を明らかにすることとし，後揭第8 四と第14四のよ5にピト一管を槽底の各要点汇植えて， 中心部静圧 $c h$ と中間部の半径方向動圧 $s h$ を計ると共 に，第 4 図と第 5 図の上弓に槽底と周壁部に一端固定の 微細絹系を流し,その流線を一平面にとれぞれ投射して， $\tan \theta, \delta R / R$ を求め, 以上の両法を伴せて上下流や内外 向流の大きさを略査した。 


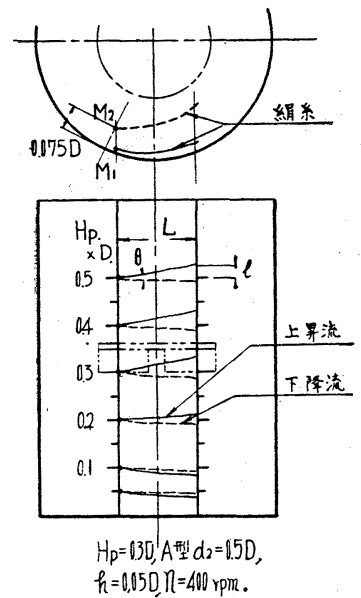

第4図絹系汅よる周壁部の フローパターンの定量

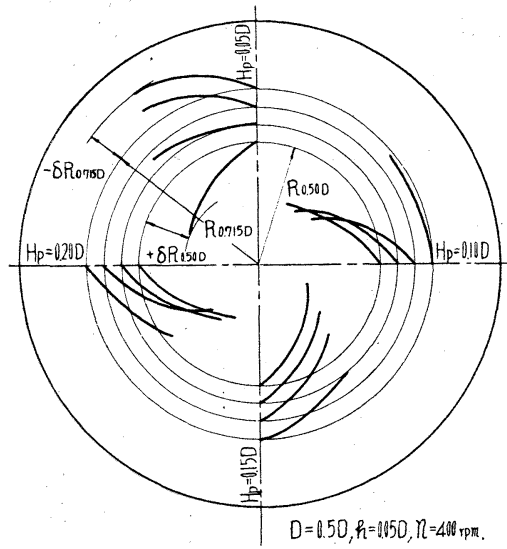

絹糸はそれぞれ別汇設置するので，各曲線は 别々汇底面汇投射されたものである。

第 5 図絹糸による槽底フロ一 パターンの定量

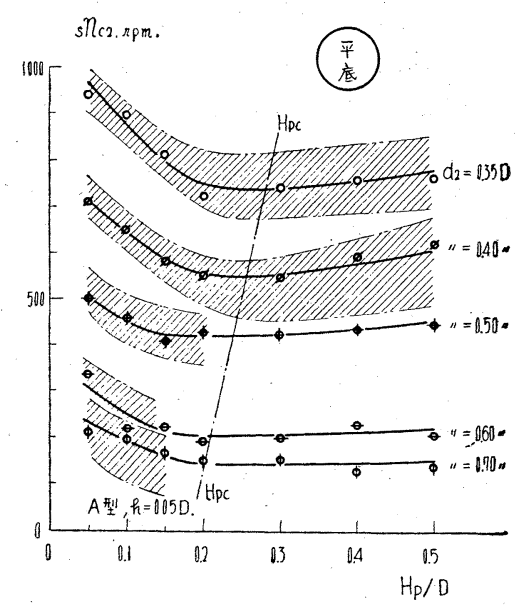

第6図 $s n_{c_{2}}$ のばらつき範囲 と $H_{p c}$ の存在

\section{3. 実験結果と論義}

\section{$3 \cdot 1$ 円筒槽 I による実験}

円筒槽の場合でる低 $H_{p}$ 亿扔忊る $H_{p}-n_{c}$ 関係とそ の水流関倸は定量的に不明である3)。この関倸を明らか 汇し，かつ角槽との対比をする意味で，帛平底の円筒槽 沉ついて実験をした。新しい結果と考学られるものは次 の通りである。

$s n_{e}$ の最小值を示す限界高度 $H_{p c}$ の存在：すでにそ の一端を第 3 図に示したが， $n_{e}$ が $H_{p}$ とともに増すに 反し, $s n_{c}$ 注最小值と示す $H_{p c}$ が存在し, $H_{p}>H_{p c}$ と なつて初めて $H_{p}$ とともに増加する。

第6 図は各々 $d_{2}$ について末とめたものであり， $d_{2}$ の 大きい活ど $H_{p c}$ は小さい(斜線内がばらつき範囲，斜 線のない曲線部はさらに不確実のところ)。

同時流動インペラ径 $d_{2 s}$ と $H_{p}$ d) : 第 3 図で $s_{1}, s_{2}$ と

d) 交献 3)，適当径 $d_{2}$ のときは $s n_{c}=c n_{c}$ となる。この $d_{2}$ を同時 流動インペラ径とよぶ。この $d_{2 s}$ 法 $H p$ 汇よつて活とんど差がな いとされている。

e）交献 4)，Hp 飞よつて流動の様式がわかることを櫂型インペラの 場合沉いて定性的注一応指摘されている。
して示した通り， $d_{2 s}$ は $H_{p}$ と密接に関連し，低 $H_{p}$ ほ ぞ大径のものとなる。

槽底流動の様式と $H_{p}{ }^{\mathrm{e})}$ : 筆者達の場合も, 内容は異 なるが, $H_{p}$ で様式が第 7 図の5うに相違している。(イ) 図のE領域に位する粒子は $s n_{c}$ が上昇して子停滞振動し て流動しにくく，この現象と $s n_{c}$ 曲線に最低值のある傾

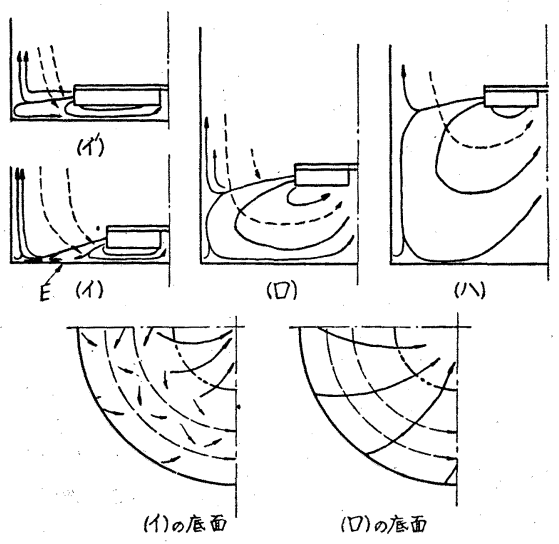

第 7 図 円筒槽下部のフローパターンの様式

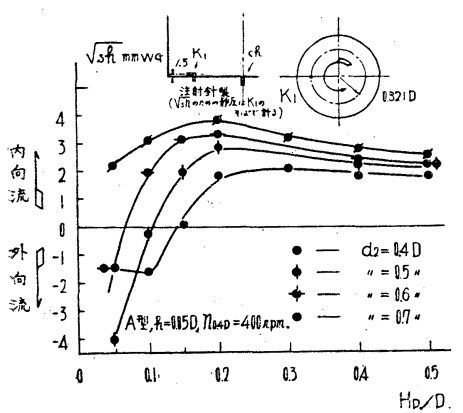

(1)

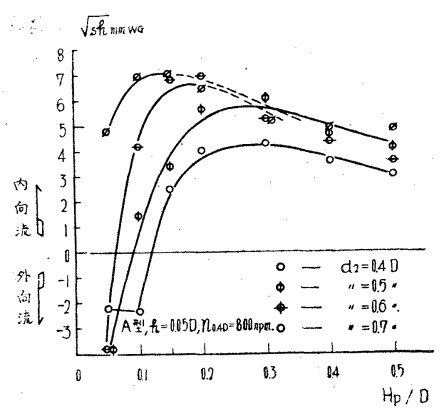

(口)

第 8 図ピトー管による槽底内外流の大きさの比較とインペラ径

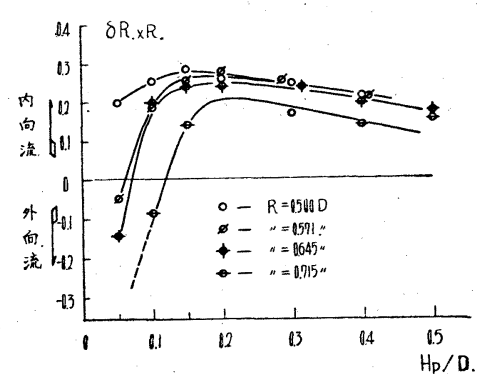

第 9 図絹糸ではかつた槽底内 外流の大きさの比較 


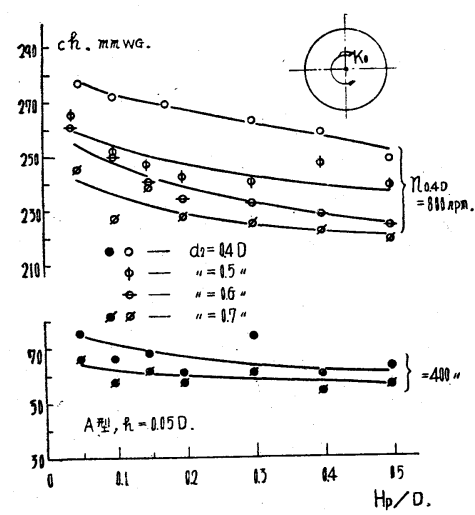

第10図 インペラ径と槽底中心の負珐

向とはよく関連する。

この関連を $K_{1}$ 点に対文る $\sqrt{s} h-H_{p}$ 曲線と $N_{1}, N_{2}$ 点などに対する $\delta R / R-H_{p}$ 曲線に上つて確か内ると， 第 8 図と第 9 図となり，両図は上く傾向が一致し，併せ て, $H_{p}$ の高低によつて周壁からの巻返り速度が相違し， 同一周速では $d_{2}$ の大きい程低 $H_{p}$ でよく巻返り, 全底 面にわたる内向き流れが完成して, より早く $\mathrm{E}$ 領域が消 失寸ることを証明し, $H_{p c}$ 值がより低くい位置に移るこ とを理解させる。

な特， $K_{0}$ 点についての $c h-H_{p}$ 曲線を念のため揭げ ると第 10 眼となり， $n_{c}-H_{p}$ 曲線の傾向を十分に裏つ けする。

周壁流動の様式と $H_{p}$ : 第 5 図の $M_{1}, M_{2}$ 点につい て $\tan \theta$ を計ると第11図となり，周壁に沿つて上昇した 流れは, 再びその内側を下降し, インペラ下底に入つて 内向流となる。この上下流の変化と第 8 注, 第10図を併 せると第 7 四の上らな循環が推察される。

\section{$3 \cdot 2$ 角槽 II による実験（扁平底）}

この場合の結果は次の通りである。

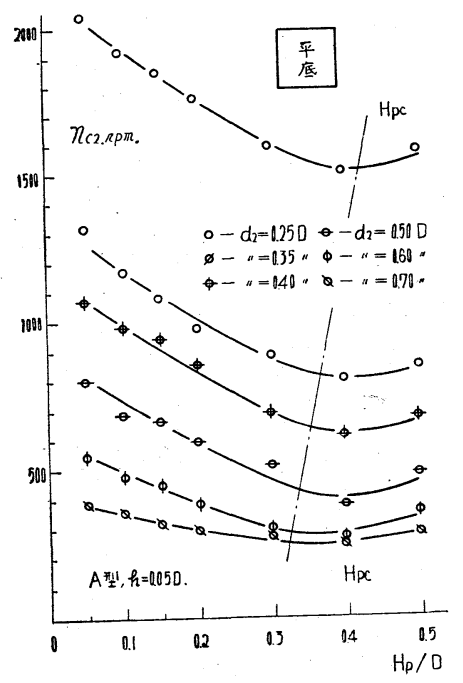

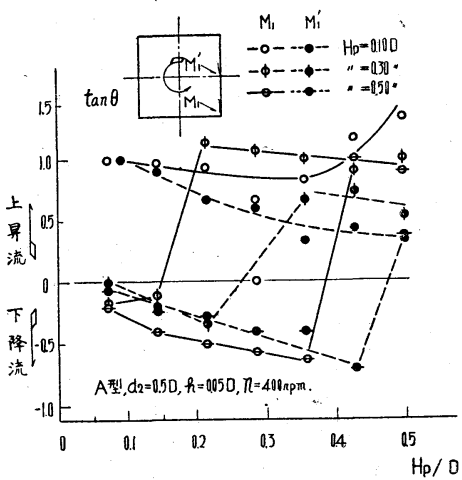

第13図 周壁上下流の大きさの比 較とインペラ設置高度

第12図 扁平底による $H_{p c}$ の上昇

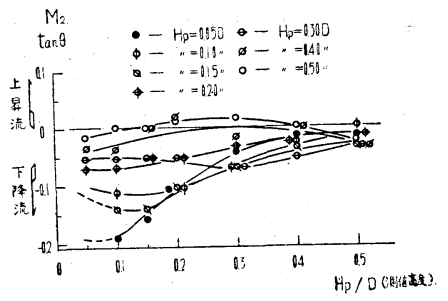

(ㅁ)

第11図 周壁上下流の大きさの比較 とインペラ設置高度
$n_{c_{2}}-H_{p}$ : この関係は第12図となり，円筒槽と違つて 隅の部分の粒子の流動が困難となつて, 低 $H_{p}$ 程 $s n_{c_{2}}$ が 上昇し, $H_{p c}$ は円筒槽の $\leq 0.3 D$ に比して $\leq 0.4 D$ と やや増高しているが， $H_{p c}$ に抢ける $s n_{c 2}$ 值は円筒槽の それとほぼ同様である。

流動の樣式と $H_{p}$ : この場合の周壁流について $\tan \theta^{\prime}$ を $M_{1}, M_{1}^{\prime}$ 点で計ると第 13 図, $K_{0}, K_{1}, K_{2}$ などにつ いて chと $\sqrt{s h}$ を求めると第14図となる。これらの圀 から,それぞれの内容は円筒槽と大分異なるものの, $H_{p}$ の高低による流動様式の变化は依然存在し, $H_{p e}$ が高 值に移動し, 一般に円筒槽に比して上下流が強く, とく に高 $H_{p}$ で顕著な下降流となるなどが確認される。この 最後の現象は $H_{p c}$ に括ける $s n_{c 2}$ 值が円筒槽のそれに近 いことを意外々させない原因となるものと考杂させる。

既掲の第 2 図のシンポリックの流根図は，この場合の ものである。すなわち(イ)図の $\mathrm{E}$ 領域は第7ー(イ)図の $\mathrm{E}$ 領域と類似の原因による粒子の停滞振動域である。一 方(ハ)図の $\mathrm{E}^{\prime}$ 領域は既述のとおり早く透明化する領域 でこの存在は下降流がここにあたつてょく清掃するも のの，その後槽底を狺わうず，斜に急上昇してインペラ中 


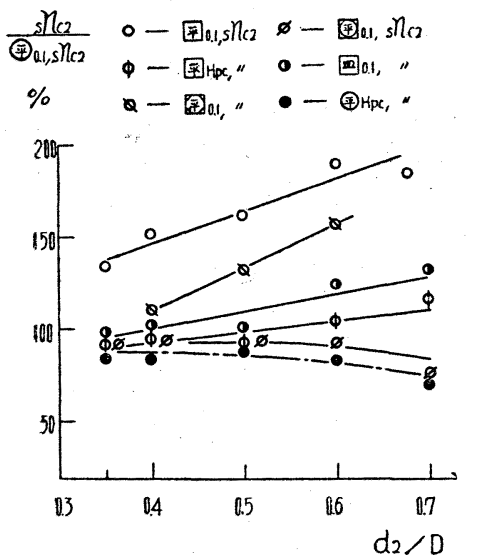

第15図 槽の形状による $s n_{c_{2}}$ の比較

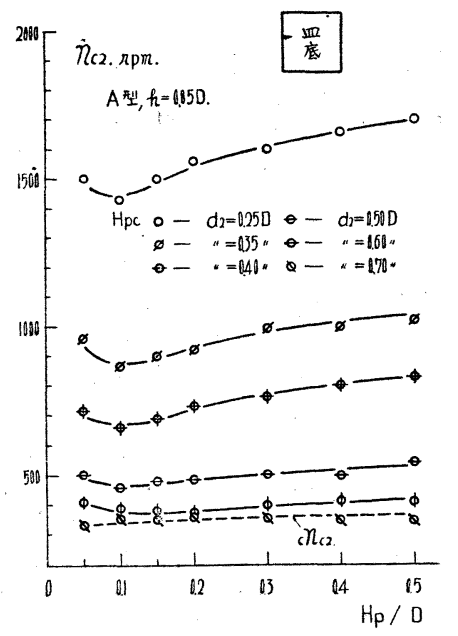

第16図 皿型底による $H_{p c}$ の引下げ
心に向うことを示すものであつて，この生成は $s n_{c_{2}}$ 值の 引下げには効果がない。結局(口)図の状態のとさ粒子は よく槽底全面にわたつて円滑に流動する。すなわちこれ が $H_{p c}$ に相当する流相である。

同時流動インペラ径 $d_{2 s}: H_{p e}$ で (0.6〜0.7) D であ り，当然大きくなつているが，換算すれば $(0.4 〜 0.5)$ $\sqrt{2 D}$ となり，対角線長からすれば円筒槽に打けると同 比率である。

\section{$3 \cdot 3$ 角槽 II'による実験（II の隅をつぶした場合）}

実技で槽の下底部のみを円形としたり，隅をつぶした 構造がある。この機能を確かめる意味で， I' 槽のよう に隅をTの $\triangle$ 型ブロックでつぶし $n_{c_{2}}-H_{p}$ 曲線を求め ると, その傾向は扁平底角槽と円筒槽の中間にあるに過 ぎず,格別 $H_{p c}$ の引下げには効果を示さないが, $H_{p c}$ と $H_{p}=0.1 D$ に和ける $s n_{e_{2}}$ を比較すると第 15 园となり， $s n_{c_{2}, 0.1}$ 值 $\left(H_{p}=0.1 D\right.$ に打りる $s n_{c_{2}}$, 以後同様とする $)$ そのものは角槽より 20 〜 30\%減となる。

\section{4 角槽 III による実験（四型底）}

実技の多くは四型底となつており，円筒槽の場合はこ

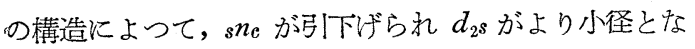
るとされている3）が，角槽についてはな扣別の效果があ るものと推察したので, 角槽IIIについて以上の実験に専 用したA型インペラのほかに $\mathrm{A}^{\prime}$ ， B，C の別型を加兄て 実験した。その結果は次の通りである。

$n_{e_{2}}-d_{2}-H_{p e}: d_{2}$ だけを変数としたA型について $n_{c_{2}}$ 一 $H_{p}$ 曲線を求めると第 16 図となる。この結果では $d_{2}$ 飞よる $H_{p c}$ の相違までは明確でないが, $H_{p c} \leq 0.1 〜 0.15$ $D$ と移り, この場合の最底 $n_{c_{2}}$ 值は扁平底の場合とほ 症同值であり，四型底の円筒槽では見られない現象〕を 示す。

f）筆者の実験，未発表，1949年度鹿児島大学工学部紀要飞発表の予定

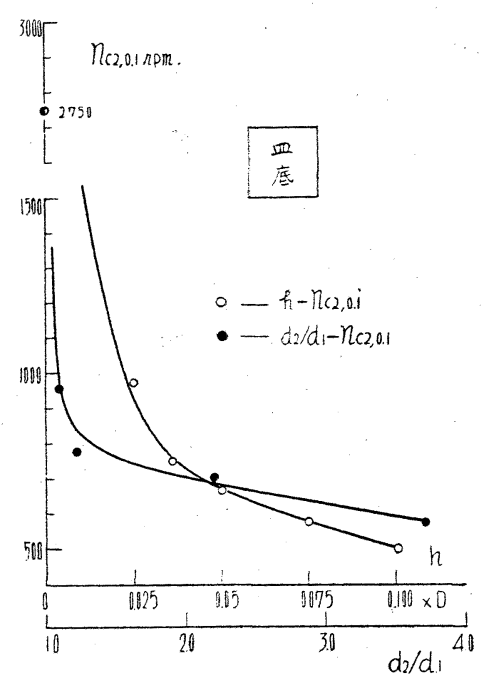

第17図、 $h$ と $d_{2} / d_{1}$ の $n_{c_{2}}$ におよ ほす影響の比較

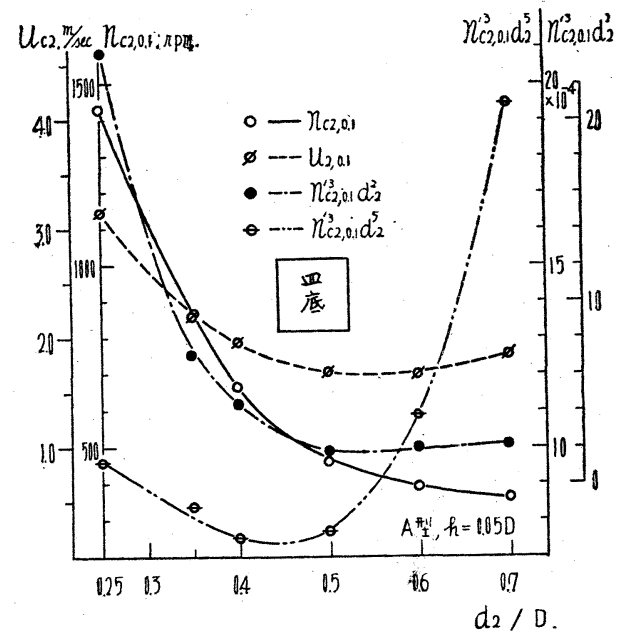

第18図 最適インペラを求めるための比較

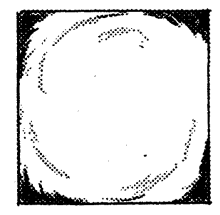

$H_{p}=0.05 D$

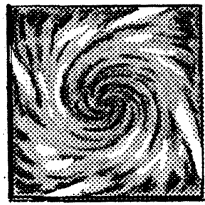

$H p=0.3 D$

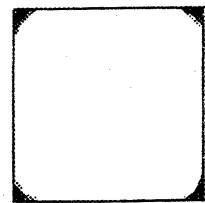

$H p=0.1 D$

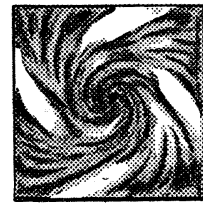

$H p=0.4 D$

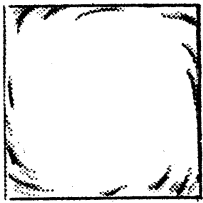

$H_{p}=0.2 D$

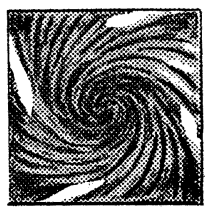

$H p=0.5 D$
第19図 槽底のフローパターン, $\mathrm{A}$ 型 $d_{2}=0.5 D$, $h=0.05 D, 460 \mathrm{rpm}$, 角槽 III（皿型底） 
この $H_{p c}$ を中心とした曲線の左右部分についてそれ ぞれの傾斜を比較すると， $d_{2}$ の大きいほど緩勾配であ 门，乙たがつて，d $d_{2}$ の大きい汪ど $H_{p c}$ 以下にインペラ を設置しても $n_{c_{2}}$ の増加は少ないことがわかる（次の ¿ $d_{2} / d_{1}$ について子同様)。

$n_{e_{2}}-h ; n_{c_{2}}-d_{2} / d_{1}$ : 同径のA型で $h$ 変光た場合と, 同径，同高の $\mathrm{A}^{\prime}$ 型で $d_{2} / d_{1}$ を変光た場合の关れぞれに ついて $n_{c_{2}}$ を求め， $s n_{c_{2}, 01}$ についてまとめると第 17 区 之なる。この傾向は円筒槽に招ける櫂型インペラの動力 比較值 ${ }^{566)}$ を逆值としたものと類似している。

$\left.u_{2} ; n^{\prime 3}{ }_{c_{2}, 0 \cdot 1} d^{2}{ }_{2}{ }^{7}\right) ; n^{\prime 3}{ }_{c_{2}, 0 \cdot 1} d^{5}{ }_{2}{ }^{8}-d_{2}$ ：第16四について 外周速 $u_{2}$ その他の量 $\left(n^{\prime}\right.$ は rps) を比較すると第 18 园 となる。この場合は高乱流域岛に属し，レイルルズ数に よる変化はないので8，相似則の不成立を無視して動力 係数を同一值と仮定すれば，動力最底の $d_{2}$ は $0.45 \mathrm{D}$ 之 見当づけられる。この值は円筒槽の場合 ${ }^{3)}$ と類似してい る。

このことは槽底攪汼に関さる限り, 槽底を血型 $(r=$ 0.15D) にした角槽は円筒槽と同一大きさのインペラで 汴ほ同一の効果を上げることを意味する。

流動の様式上 $H_{p}$ : 第16図の裹づけのため, 同一 $n_{c_{2}}$ $=460 \mathrm{rpm}\left(H_{p c}\right.$ に招ける $n_{c 2}$ の值)を使って, 各 $H_{p}$ 汇対応する槽底の粒子の流相をスケッチすると第19図と なり，槽底の要点に流した絹系の流れ方向とその立上り 角を例示すると第20図となる。

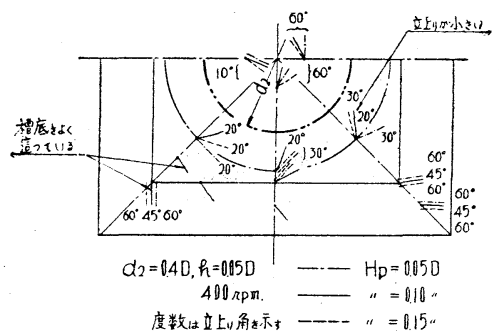

\section{第20図}

絹糸による槽 底フローパタ ーンの判定, 角槽 III

以上の両図から $H_{p} \cong 0.1 D$ の場合が，底面の大部分 江执いて，周壁からの巻返しが強く円滑であり，内向流 が底面に上く沿つて中心へと連続流動し, 隅の部分の外 向流れるよく底面を這い，粒子の停膟域がないことがわ かる。

$\mathrm{B}$ 型と $\mathrm{A}$ 型の比較 : 実技用の副羽根俚平羽根でなく, 三角または変形三角羽根が多い。この点を考慮してA, B 型を比較すると第21図となり，同羽根面積では B 型が劣 り， $H_{p}$ の高い注どその差が大きい。

立羽根と副羽根作用 : 空気の巻込防止のため邪魔羽根 を插入し，同径の $\mathrm{A} ， \mathrm{C}$ 型を対比使用すると，その $n_{c_{2}}$

g) $n_{c 2,0.1} d^{2}{ }_{2} \cdot \frac{\rho}{\eta} \cong(4.35 \sim 8.16) 10^{4}$, ただし. $d_{2}=(0.4 \sim 0.7) D$ で $25^{\circ} \mathrm{G}$ の場合。 $\eta$ は水の粘性倸数, $\rho$ 注との比重。
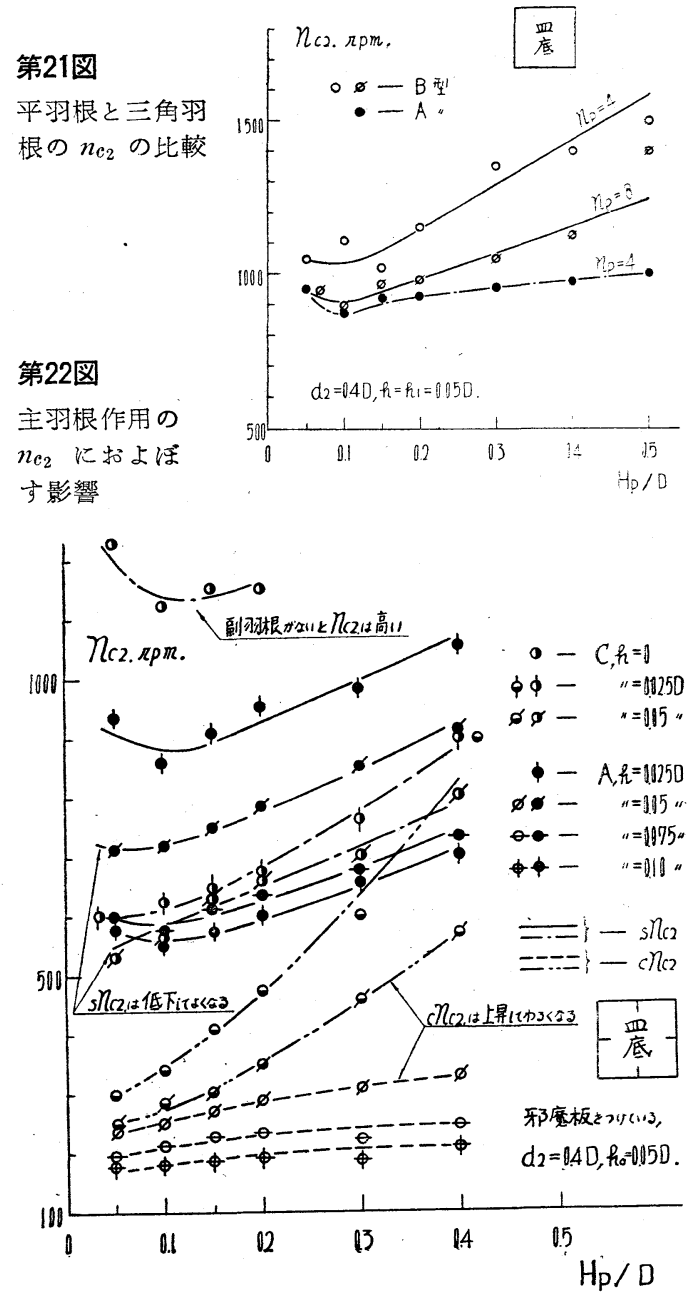

$-H_{p}$ 関倸は第22図となる。

この罒から, 主羽根を加えたものを低 $H_{p}$ で使用すれ ば，中心部の吸上げ作用はかえつて若干劣化するが，周 壁部の粒子の流動は良好となつて $s n_{c_{2}}$ が低下し，笛の 低下する度合は $h+h_{0}$ に等しい羽根高さの副羽根によ るものと近似することと, 高 $H_{p}$ で使用するほど ${ }^{n} n_{e_{2}}$ が ますます劣化され, $s n_{\mathfrak{c}_{2}}$ 引下げの効果も急激に減衰する ことがわかる。

\section{4. $>\boldsymbol{n}_{c 2}$ の回転数と $\boldsymbol{H}_{p c}$}

実技インペラの外周速は本実験の範囲以上に高い。し たがつて $H_{p c}$ においてそれに対応する $n_{c 2}$ 以上で使用 された場合の現象を考慮する必要がある。

インペラの回転数が変化すると $H_{p c}$ の位置が変動す る事実は, 円筒槽に捛ける第 3 図で, $H_{0}$ 点が $0.15 D$ 付近に低くなつていることで証明済であるが，さらに明 確とするため第 8 図の例示のような結果を利用し，最大 $+\sqrt{s h}$ 值を示す $H_{p}$ を求め, 回転数とこの $H_{p}$ との 


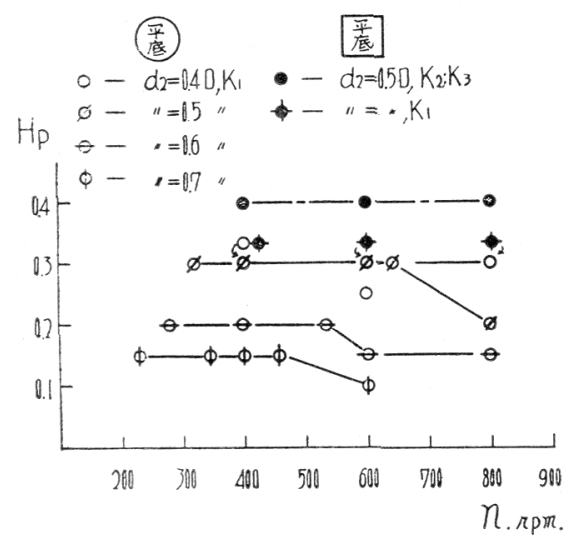

第23図最大 $\sqrt{s h}$ 走示 $H_{p}$ とインペラ回転数

関係を調ベると第23図となり，一屠はつきりする。

そこで同㥞のことが吕の且底角榑に存在するかど5か

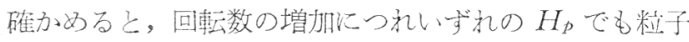

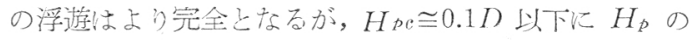
移ることは確認できなかつた。

このここは，副羽根単独では槽の幾何学的条件と関連 する流動梯式の制限を越光る $H_{p c}$ の引下げは不可能で 西り，立羽根学加党て低 $H_{p}$ で運忶した場合に笑現し た $H_{p c}<0.1 D$ のらなことは見出せないことを示す。

\section{5. 結} 言

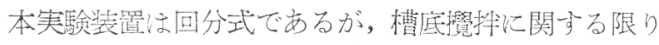
では連続式と類似の流相を致開するので，この寒験結果
は，浮選槽底と副羽根に関卞合奏技構造の機能を示し， 設計けための資料しなるものと考える。

結果を要約する上次の通りとなる。

1）槽と副羽根との幾何学的条件により，槽底䊀子に 刘与る流動様式が異なり，流動限界凁度が違５。

2）特定のインペラ設置高度で最小の周壁部流動限界 速度を与光当(笑技用の $d_{2}$ の大ささでは $s n_{e}>c n_{e}$ な

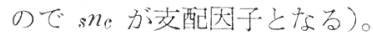

3）皿型底や主羽根の作用は限界高度と限界速度を尼! 下げる效果壱もつ。

4）インペラの笑搷的設置高度とこの限界高度とを一 致させることは, 最適の副妆根で必要な槽底撜找を笑現 することを意味し，無用な動力の消費を防止することと なる。

謝辞：本実験にあたつて，交献や助言を戴いた東工大 椻谷松樹, 森永卓一; 東大, 今泉常正; 九大, 湯浅陽一 の各先生之, 引用文献の篗者である京大, 永王進治; 批 判美戴いた京大中川有三の各先生に深謝中上げる。

\section{参考文献}

1) Hixson, A. W.,A. H. Tenney: Trars. A. I. C. E., 31, 113 (1934), White, A. M., et al: Ind. Eng. Chem, 24, 1160 (1932).

2) 大山・遠藤：化学工学, 20,666 (1956)

3) 永田・横山・南条：同上, 17, 98 (1953).

4) 永田・横山・北村：同上, 17, 95 (1953).

5) 永田：化学機械技街 第 9 集, 187 (1957).

6)永田・横山・裤滕: 化学工学, 18, 228 (1954).

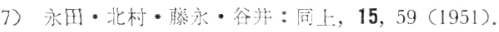

8)河東・山本・石川! : 目上, 17, 236 (1953).

\section{有機重液による浮沈試験とその回收法}

浮沈試験当行うには中間比重の雷 液が必要であるが，それには沃化メ チレン $\mathrm{CH}_{2} \mathrm{I}_{2}$ (比重 3.30 ) とベンゼ $\mathrm{C}_{6} \mathrm{H}_{6}$ (比重 0.86 )，またはテト ラブロムニタン $\mathrm{CHBr}_{2} \mathrm{CHBr}_{2}$ (比 重 2.96) と四塩化炭素 $\mathrm{CCl}_{4}$ (比而 1.60）の混合液が普通用いられてい る(第 1 表第 2 㤗)。

浮沈試験によつて分離した産物は

\section{第1表 テトラブロムェタ ンと四塩化炭素混 合液の比重}

\begin{tabular}{c|c|c}
\hline $\mathrm{CHBr}_{2}: \mathrm{CHBr}_{2}$ & $\mathrm{CCl}_{4} \mathrm{~m} l$ & 液の此正 \\
\hline $\mathrm{m} l$ & 0 & 2.96 \\
80 & 2 & 2.93 \\
80 & 6 & 2.89 \\
80 & 10 & 2.81 \\
80 & 16 & 2.73 \\
80 & 20 & 2.69 \\
80 & 20 & 1.60 \\
0 & &
\end{tabular}

乾燥と科量に先立つて重液老除くた めにアセトンで完全に洗う必要が あり，この際重液の損失を生ずる。

この重液は水とよく混ぜることによ つて，アセトン洗熦液から回收する ことができる。アセトンは我と混ざ りやすいから，重いテトラブロムェ タンは容器の底に沈み, 容易に回收 できる。(写真参照)

第2表 沃化メチレンとに
ソゼン混合液の比
重

\begin{tabular}{c|c|c}
$\mathrm{CH}_{2} \mathrm{I}_{2} \mathrm{~m} l$ & $\mathrm{C}_{6} \mathrm{H}_{6} \mathrm{~m} l$ & 液 の比重 \\
\hline 100 & 0 & 3.30 \\
95 & 5 & 3.18 \\
90 & 10 & 3.05 \\
85 & 15 & 2.93 \\
80 & 20 & 2.81 \\
75 & 25 & 2.70 \\
0 & 100 & 0.86
\end{tabular}

(32)

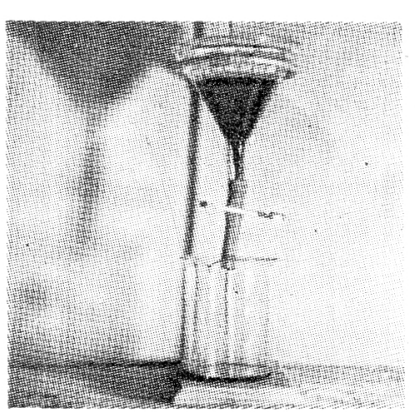

またテトラブロムエタン系ないし 沃化丈チレン系の重液は，それだれ 四塩化炭素ないしベンゼンの沸点 (前者は $76 \sim 77^{\circ} \mathrm{C}$ ，後者は $80^{\circ} \mathrm{C}$ ) まで水浴中で暧めることによつて再 生ずることができる。ただしこの作 籍は, 浮沈試験の澡作々同棣, フー ドの下で適当な換気当行いつつやら なけ机ばならない。(DECO Trefoil, Mar.Apr., 1957 \&) (井上外志雄) 